\title{
A Cross-sectional Analysis of Classroom Assessment Skills and Practices across Levels in a Catholic Educational Institution
}

\author{
Prof. Dr. Segundo Chavez Redondo, Jr., Prof. Dr. David Cababaro Bueno and Prof. Dr. Narcisa Ruano \\ Figuerres
}

\begin{abstract}
This study concentrated on the analysis of the classroom assessment skills and practices of teachers across levels in a private Catholic school. The descriptive crosssectional design was utilized to gather descriptive and comparative data during the Academic Year 2017-2018. All teachers from elementary, junior and senior high school were considered as participants. The Classroom Assessment Practices and Skills (CAPS) questionnaire was used. Reliability estimates of teachers' perceived skill in classroom assessment were done using Cronbach's Alpha, which was $\alpha=$ .95 indicating high levels of internal consistency. The data gathered were analyzed using Mean, and Analysis of Variance (ANOVA) at .05 level of confidence. The teachers across levels are very skilled in calculating central tendency of teachermade tests, assessing students' class participation, using assessment results in planning, decision-making, communicating and providing feedback, problem solving, evaluating class improvement, and writing true or false tests. Moreover, they are skilled in writing multiple-choice tests measuring higher order thinking skills (HOTS). They always prepare and employ multiple-choice question, true or false and essay questions, HOTS, problem solving, assessment results for decision-making and written feedback along with student's grades. Furthermore, there is a moderate positive correlation between the assessment skills and practices of elementary, junior, and senior high school teachers. Traditional forms of assessment are more preferred by the teachers compared to the alternative assessment.
\end{abstract}

Keywords - Classroom assessment, skills and practices, crosssectional design, elementary, junior and senior high school teachers

Manuscript submitted on May 14, 2018 for review. This work was funded by the Research and Publications Office of Columban College, Inc.,-- Olongapo City, Philippines.

*The first author is Principal of the Basic Education Department and concurrent Director of Research and Publications Office of Columban College, Inc.-Olongapo City, Philippines.

**The second author is Dean of the Graduate School and concurrent Dean of College of Education, Arts and Sciences.

***The third author is a Graduate School Professor and concurrent Ed.D. Program Chair and Research Coordinator of the Graduate School Programs at Columban College, Inc.

\section{INTRODUCTION}

Educational assessment is an essential component of the teaching profession. It is the process used in the classroom by the teacher to obtain information about students' performances on assessment tasks, using a variety of assessment methods, to determine the extent to which students are achieving the target instructional outcomes. In this regard, researchers suggest that a sound educational assessment requires a clear conception of all intended learning outcomes of the instruction and a variety of assessment procedures that are relevant to the instruction, adequate to sample student performance, and fair to everyone. This means teachers should competently be able to choose and develop assessment methods appropriate for instructional decisions; administer, score, and interpret results of externally produced and teacher-made assessment; use assessment results when making educational decisions; develop valid grading procedures; communicate assessment results to various audiences; and recognize unethical, illegal, and inappropriate methods and uses of assessment (Alkharusi, Aldhafri, Alnabhani, \& Alkalbani, 2012). Thus, teaching is a multifaceted process that requires teacher competencies in measurement and assessment skills. Such skills may include: test planning and construction; grading; interpretation of test results; use of assessment results to inform teaching and learning; interpretation of standardized tests; and communicating results to relevant stakeholders (Koloi-keaikitse, 2017).

Assessment of students is very critical because effective teaching decisions are based on the ability of teachers to understand their students and to match actions with accurate assessments (McMillan, 2008). However, past research has shown that there are many problems associated with teachers' classroom assessment practices. These include teachers' lack of an adequate knowledge base regarding the basic testing and measurement concepts (Stiggins, 2014), limited teacher training in assessment and failure of teachers to employ and adhere to measurement guidelines they learned in measurement courses (Campbell \& Evans, 2000). Teachers adopt different classroom assessment practices to evaluate students' learning outcomes, and they spend much of their classroom time 
engaged in student assessment related activities. Teachers control classroom assessment environments by choosing how they assess their students, the frequency of these assessments, and how they give students feedback. All these are a clear indication that classroom assessments play an integral part of the teaching and learning process. Just like teachers everywhere, Columban College, Inc. (CCI) teachers are the key drivers of the education process. Their instructional and classroom assessment practices are a means by which the education system is enhanced and defined (Nenty, Adedoyin, Odili, \& Major, 2007). For this reason, it is imperative to understand the ways in which teachers feel about assessment practices, their perceptions regarding assessment training and their experiences as they attempt to use various assessment methods to evaluate students' learning outcomes. It is also important to understand their thought processes as they develop and use assessment methods, grade students' work and interpret assessment results. Teachers' assessment practices are an essential element for addressing students' learning needs, and they can ultimately improve the education system and accountability. Understanding teachers' assessment practices serves as a way of finding out if teachers adopt or use quality assessment methods to meet the learning needs of students (McMillan, 2008).

The role of student assessment at the various levels in the educational system is to generate information to be used for making "high stakes" decisions, such as selecting and placing students in appropriate training programs. Student assessment in a private educational institution also plays an important role of helping students prepare for standardized examinations needed for those "high stakes" decisions. However, few formal studies on teachers' classroom assessment skills and practices have been conducted. This makes it difficult to have a clear understanding about the nature and magnitude of assessment issues of teachers in the elementary to senior high school. This study endeavors to bring an awareness regarding how teachers generally perceive their classroom assessment skills and practices as paradigm shift towards outcomes-based assessment practices.

This study assessed the teacher's response pattern in a set of items that measured their perceived skills in classroom assessment practices. In order to gain insights into teacher's response to their perceived skill in assessment scale, an Item Response Theory (IRT) model was utilized. IRT refers to a set of models that connects observed item responses to a participant examinee's location on the underlying trait that is measured by the entire scale (Mellenbergh, 1994). IRT models have been found to have a number of advantages over other methods in assessing self-reported outcomes such as teacher beliefs, perceptions, and attitudes (Hambleton, Swaminathan, \&
Rogers, 1991). IRT is a general statistical theory about examinee item and test and how performance relates to the abilities that are measured by the items in the test. IRT models have the potential to highlight whether items are equivalent in meaning to different respondents, they can be used to assess items with different response patterns within the same scale of measurement, therefore can detect different item response patterns in a given scale (Hays, Morales, \& Reise, 2000). Thus, IRT is regarded as an improved version of Classical Test Theory (CTT) as many different tasks may be performed through IRT models that provide more flexible information. Test items and traits of the test taker are referenced on the same interval scale (Koloi-keaikitse, 2017). Thus, in order to understand what students know or do not know, educators need assessment. Classroom assessment is possibly the first and most important part of the teaching and learning process that includes measurement, feedback, reflection, and change. Classroom assessments play an important role as they are essential for generating information used for making educational decisions. Classroom assessments also serve many purposes for teachers such as: grading, identification of students with special learning needs, student motivation, clarification of students' achievement expectations, and monitoring instructional effectiveness (Stiggins, \& Bridgeford, 2014). Thus, classroom assessments must be transformed into the content and use of assessment information and insights as part of an ongoing learning process. The purpose of classroom assessment is not just to generate information for decision making, but also to foster learning improvement. For this reason, if properly offered on a frequent basis it would help students to refine and deepen their understanding of what they learn. Classroom assessments are also essential for conveying expectations that can stimulate the learning (Wiggins, 2008). The more information we have about students, the clearer the picture we have about their achievement, learning challenges and where those challenges emanate. For this reason, there is a need to pay attention to how it is used, as failure to do this may lead to inaccurate assessment of students' achievement and may ultimately prevent students from reaching their full academic potential (Stiggins, \& Bridgeford, 2014). In other words, assessment serves as an important deciding factor for the future of students' learning outcomes. Educators must have a clear understanding of the assessment practices that teachers use as they assess students, and the assessment challenges teachers face. The most efficient way to measure, understand, and appreciate teachers' assessment practices is to assess their perceptions about classroom assessment methods. Classroom assessment involves a wide range of activities from designing paper-pencil tests and performance measures to grading, communicating 
assessment results, and using them in decision-making (Zhang \& Burry-Stock, 2013). Although there is a great deal of research on teachers' assessment practices, few empirical research attempts have been made to link these practices to teachers' skills in the classroom assessment environment.

Thus, there is no empirical investigation on comparative analysis of the classroom assessment skills and practices of the basic education teachers from elementary to senior high school that demonstrates comparative analysis. Given the paucity of such research, Cavanagh et al. (2005) suggest that two strategies can instead be applied: (1) examine the assessment skills in terms of forms/approaches, and (2) examine the actual assessment practices that teachers use. Integrating teachers' perceptions will build a foundation and rationale for the assessment practice they use in their classrooms, through which one can learn to what extent and in what ways students' impacts their learning. Thus, the purpose of this study is to examine assessment skills and practices about assessment of teachers particularly in a private educational system.

\section{OBJECTIVE OF The STUDY}

This study focused on the classroom assessment practices of teachers across levels and departments towards outcomes-based assessment model. The specific objectives of the study are to analyze: (1) the skills of teachers in the areas of classroom assessment; (2) the practices of teachers related to classroom assessment; and (3) relationship between the classroom assessment skills and practices of the teachers.

\section{METHODOLOGY}

A descriptive-cross-sectional design was used to gather descriptive and comparative data for the purpose of describing the characteristics of several groups of teachers relative to their classroom assessment practices. Descriptive cross-sectional design is used to describe characteristics of a population or phenomenon being studied at a given time. It does not answer questions about how/when/why the characteristics occurred. Rather it addresses the "what" question. The characteristics used to describe the situation or population is usually some kind of categorical scheme also known as descriptive categories. Surveys can be a powerful and useful tool for collecting data on human characteristics, such as their beliefs, attitudes, thoughts, and behavior (Dillman, Smtyth, \& Christian, 2009; Gay, Mills, \& Airasian, 2009; Mertens, 2014), hence the survey design fit very well within the framework of this study. All teachers from various levels were covered in this study. Thus, there was no sampling technique used. The elementary school teachers, junior high school and the senior high teachers were included. The Classroom Assessment Practices and Skills (CAPS) questionnaire was used as the data collection instrument. The questionnaire contains closed-ended items. The initial set of items was adopted from Assessment Practices Inventory (Zhang \& Burry-Stock, 2013). This instrument was created and used in the United States of America to measure teachers' skills and use of assessment practices across teaching levels, content areas, and teachers selfperceived assessment skills as a function of teaching experience. The Zhang \& Burry-Stock (2013) instrument consists of several items measured on two rating scales "use" and "skill" The "use" scale was meant to measure teachers' usage of assessment practices on a scale from 1 (never) to 5 (always). The "skill" scale was designed to measure teachers' self-perceived from 1 (not at all skilled) to 5 (very skilled). To check the content-validity of the instrument, the draft questionnaire was given content experts in classroom assessment and teacher training. They were asked to review the items for clarity and completeness in covering most, if not all, assessment and grading practices used by teachers in classroom settings, as well as to establish face and content validity of the instrument and items. Necessary revisions were made based upon their analyses. The draft questionnaire with various items was pilot tested with a total sample of 10 teachers from primary school, 10 junior high school, and 10 senior high school to assess the strengths and weaknesses of the questionnaire in terms of question format, wording and order of items. It was also meant to help in the identification of question variation, meaning, item difficulty, and participants' interest and attention in responding to individual items, as well as to establish relationships among items and item responses, and to check item response reliability (Gay, Mills, \& Airasian, 2009; Mertens, 2014). Reliability estimates of teachers' perceived skill in classroom assessment were estimated using Cronbach's Alpha, which was $\alpha=.95$ indicating high levels of internal consistency (Bueno, 2017). The researchers sought permission and approval of the school president to allow the data gathering from teachers. The researchers took into account the ethical issues such as the confidentiality of the data gathered and the anonymity of the respondents in the administration of the questionnaires. The data gathered were analyzed using Mean, and Pearson Product Moment Correlation at .05 level of confidence.

\section{RESULTS AND DISCUSSION}

\section{A. Skills on Classroom Assessment}

The results of the previous study revealed that primary school teachers, particularly those with a certificate, need 
more skill training in assessment applications, statistical applications and criterion referenced testing. Primary school teachers reported relatively higher discrepancies on use than perceived skill for statistical applications and objective items, and secondary school teachers reported more skill than use of statistical applications and objective items (Koloi-Keaikitse, 2012). The elementary school teachers (EST) are very skilled using assessment results for decision-making about individual students, assessing individual student participation in whole class lessons, assessment of problem solving skills, using assessment results for decision-making about individual students, using assessment results when planning teaching, communicating classroom assessment results to others, including student improvement in the calculation of grades, using assessment results when evaluating class improvement, writing true or false questions, and providing written feedback comments along with grades. Moreover, the EST are skilled in writing multiple-choice questions, writing essay questions, and writing test items for higher cognitive levels. However, the EST are moderately skilled in conducting item analysis for teacher-made tests, revising a test based on item analysis, using portfolio assessment, using peer assessments for student assessments, using a table of specifications to plan assessments, developing rubrics for grading students' assignments, and calculating variability (standard deviation) for teacher-made tests. Thus, the overall mean assessment is 3.88 . This means that the elementary school teachers are skilled in conducting classroom assessment of students' learning.

The Junior High School Teachers (JHST) are very skilled in writing essay questions, calculating central tendency for teacher-made tests, assessing individual student participation in whole class lessons, assessment of problem solving skills, using assessment results for decision-making about individual students, using assessment results when planning teaching, communicating classroom assessment results to others, including student improvement in the calculation of grades, using assessment results when evaluating class improvement, writing true or false questions, and providing written feedback comments along with grades. Moreover, the JHST are skilled in writing multiple-choice questions, writing test items for higher cognitive levels, conducting item analysis for teacher-made tests, and revising a test based on item analysis. However, the JHST are moderately skilled in using portfolio assessment, using peer assessments for student assessments, using a table of specifications to plan assessments, developing rubrics for grading students' assignments, and calculating variability (standard deviation) for teacher-made tests. Thus, the overall mean assessment is 4.00 . This means that the junior high school teachers are skilled in conducting classroom assessment of students' learning.

The Senior High School Teachers (SHST) are very skilled in writing essay questions, calculating central tendency for teacher-made tests, assessing individual student participation in whole class lessons, assessment of problem solving skills, using assessment results for decision-making about individual students, using assessment results when planning teaching, communicating classroom assessment results to others, including student improvement in the calculation of grades, using assessment results when evaluating class improvement, providing written feedback comments along with grades, and writing true or false questions. Moreover, the SHST are skilled in writing multiple-choice questions, writing test items for higher cognitive levels, conducting item analysis for teacher-made tests, revising a test based on item analysis, using portfolio assessment, using peer assessments for student assessments, and using a table of specifications to plan assessments. However, the SHST are just moderately skilled in developing rubrics for grading students' assignments, and calculating variability (standard deviation) for teacher-made tests. Thus, the overall mean assessment is 4.23 . This means that the senior high school teachers are very skilled in conducting classroom assessment of students' learning. In order to gather information about teaching and learning, teachers use a variety of assessment instruments such as written tests, performance assessment, observation and portfolio assessment (Airasian, 2011; Stiggins \& Bridgeford, 2014; Popham, 2008). Ndalichako (2014) observed that most primary school teachers prefer to use tests and examinations to evaluate students' learning. However, use of multiple methods of assessment is recommended due to its potentiality in yielding valuable information regarding students' strengths and weaknesses in their learning (Gonzales \& Fuggan, 2012). There are various methods that can be used to assess students learning such as portfolios, projects, performance assessment such methods offer rich information about teaching and learning. Portfolio is generally defined as a collection of student work with a common theme or purpose (Wolf, 2011; Arter \& Spandel, 2012; Damian, 2014; Popham, 2008).

The key characteristic of portfolio assessment is that it highlights student effort, development, and achievement over a period of time and emphasizes application of knowledge rather than simply recall of information (Price, Pierson, \& Light, 2011). The main advantage of using portfolio is the engagement of students in assessing their own progress and achievement and in strengthening collaboration with their teachers through establishing ongoing learning goals (Popham, 2008). Portfolios encourage self-reflection and awareness among students as 
they review their previous assignments and assess strengths and weaknesses of both the processes as well as the final products (Sweet, 2013). The main challenges associated with use of portfolios are the reliability of scoring, time required to produce the product and to develop a credible scoring system. The findings of the present study affirmed the investigation on teachers' assessment practices across teaching levels and content areas, as well as teachers' selfperceived assessment skills as a function of teaching experience and measurement training (Zhang \& Burrystock, 2003). Thus, classroom assessment has received increased attention from the measurement community in recent years. Since teachers are primarily responsible for evaluating instruction and student learning, there is a widespread concern about the quality of classroom assessment (Mullis \& Martin, 2015). More research has confirmed this general picture. Elementary teachers appear to be unaware of the assessment work and do not trust or use their authentic assessment results (Florez \& Sammons, 2017). Both in questioning and written work, teachers' assessment focuses on low-level aims, mainly recall. There is little focus on such outcomes as speculation and critical reflection (Ndalichako, 2013), and students focus on getting through the tasks and resist attempts to engage in risky cognitive activities (Chih-Min, S. \& Li-Yi, W., 2016). Although teachers can predict the performance of their pupils, their own assessments do not tell them what they need to know about their students' learning (Bombly, 2013).

\section{B. Classroom Assessment Practices}

Proper choice of classroom assessment method allows teachers to diagnose problems faced by students in attaining desirable learning outcomes and in devising appropriate remedial measures to redress the situation (Looney, Cumming, Kleij, \& Harris, 2017). In a nutshell, classroom assessment can be viewed as a totality of all the processes and procedures used to gather useful information about the progress in teaching and learning which facilitates in regulating the pace and strategies of teaching. Frequency of assessment is also considered important in facilitating retention of material learned (Panadero, Brown \& Courtney, 2014). They observed that the frequency of assessment has a mediating effect on student engagement in learning. Research by Pryor and Crossouard (2010) showed that when the frequency of testing is increased, there is increased student involvement in responding to questions and in discussing the subject matter. Other scholars maintained that frequent testing helps students to monitor their learning and reinforces their engagement with the course as a result of immediate feedback provided (Lysaght \& O’Leary, 2013). It has also been established that frequent testing has positive impact on future retention of material learned (Looney, 2014). Since retention of material is one of an important components of master learning (Panadero, Brown \& Courtney, 2014), it can be inferred that frequent testing contributes to mastery learning.

The Elementary School Teachers (EST) are always using multiple-choice questions, essay questions, test items for higher cognitive levels, assessment of problem solving skills, using assessment results for decision-making about individual students, writing true or false questions, and always providing written feedback comments along with grades. The EST oftentimes assess individual student participation in whole class lessons, use assessment results when planning teaching, communicate classroom assessment results to others, include student improvement in the calculation of grades, use a table of specifications to plan assessments, and assessment results when evaluating class improvement. Moreover, the EST sometimes calculate central tendency for teacher-made tests, conduct item analysis for teacher-made tests, revise a test based on item analysis, use portfolio assessment, use peer assessments for student assessments, and develop rubrics for grading students' assignments. Thus, the teachers seldom calculate variability (standard deviation) for teacher-made tests. The overall mean assessment is 3.64. This means that the elementary school teachers oftentimes use these assessment tools for students' learning.

The Junior High School Teachers (JHST) are always using multiple-choice questions, essay questions, true or false questions, writing test items for higher cognitive levels, problem solving skills, assessment results for decision-making about individual students, and always providing written feedback comments along with grades. The feedback provided by teachers' written responses to students' homework was studied in an experiment with students involving teachers in schools (Wyatt-Smith \& Klenowski, 2013). They trained the teachers to give written feedback which concentrated on specific errors and on poor strategy, with suggestions about how to improve, the whole being guided by a focus on deep rather than superficial learning (Wyatt-Smith \& Looney, 2016). Analysis of variance of the results showed a big effect associated with the feedback treatment in the final achievement. The treatment also reduced the initial superiority of boys over girls and had a large positive effect on attitudes towards the subject (Xu \& Brown, 2016). Moreover, the JHST oftentimes calculate central tendency for teacher-made tests, assess individual student participation in whole class lessons, use portfolio assessment, use assessment results when planning teaching, communicate classroom assessment results to others, include student improvement in the calculation of grades, use a table of specifications to plan assessments, and assessment results when evaluating class improvement. Furthermore, the teachers sometimes 
conduct item analysis for teacher-made tests, and revise a test items, use peer assessments for student assessments, and develop rubrics for grading students' assignments. The portfolio movement is more closely associated with efforts to change the impact of high-stakes, often standardized, testing of school learning (Young, \& Jackman, 2014). There is a vast literature associated with the portfolio movement. Much of it is reviewed by DeLuca \& Klinger, 2010), set out some of the issues in education. A portfolio is a collection of a student's work, usually constructed by selection from a larger corpus and often presented with a reflective piece written by the student to justify the selection (Cizek, Schmid, \& Germuth, 2013). Others (Alkharusi et al., 2012) emphasize that it is valuable for students to understand the assessment criteria for themselves, while Brookhart (2011), points out that the practice of helping students to reflect on their work has made teachers more reflective for themselves. However, there is little by way of research evidence that goes beyond the reports of teachers, to establish the learning advantages. Attention has focused rather on the reliability of teachers' scoring of portfolios because of the motive to make them satisfy concerns for accountability, and so to serve summative purposes as well as the formative (Koh, 2011). In this regard, the tension between the purposes plays out both in the selection and in the scoring of tasks. Lyon (2011) describes scoring approaches based on a multidimensional approach, with the criterion that each dimension reflects an aspect of learning which can be understood by students and which reflects an important aspect of learning. However, the Junior High School Teachers seldom calculate variability (standard deviation) for teacher-made tests. Thus, the overall mean assessment is 3.73. This means that the JHST oftentimes use these assessment tools for students' learning.

The Senior High School Teachers (SHST) are always using multiple-choice questions, essay questions, true or false questions, writing test items for higher cognitive levels, problem solving skills, assessment results for decision-making about individual students, and always providing written feedback comments along with grades. Moreover, the SHST oftentimes calculate central tendency for teacher-made tests, assess individual student participation in whole class lessons, use portfolio assessment, use assessment results when planning teaching, communicate classroom assessment results to others, include student improvement in the calculation of grades, use a table of specifications to plan assessments, and assessment results when evaluating class improvement. Furthermore, the teachers sometimes conduct item analysis for teacher-made tests, and revise a test items, use peer assessments for student assessments, and develop rubrics for grading students' assignments. However, the Senior
High School Teachers seldom calculate variability (standard deviation) for teacher-made tests. Thus, the overall mean assessment is 3.83. This means that the SHST oftentimes use these assessment tools for students' learning. More than one assessment method should be used to ensure comprehensive and consistent indications of student performance (Alkharusi et al., 2012). This means to obtain a more complete picture or profile of a student's knowledge, skills, attitudes, or behaviors and to discern consistent patterns and trends, more than one assessment method should be used. Student knowledge might be assessed using completion items; process or reasoning skills might be assessed by observing performance on a relevant task; evaluation skills might be assessed by reflecting upon the discussion with a student about what materials to include in a portfolio. Self-assessment may help to clarify and add meaning to the assessment of a written communication, science project, piece of art work, or an attitude. Use of more than one method will also help minimize inconsistency brought about by different sources of measurement error. Before an assessment method is used, a procedure for scoring should be prepared to guide the process of judging the quality of a performance or product, the appropriateness of an attitude or behavior, or the correctness of an answer (Zhang \& Burry-Stock, 2013). It means further that to increase consistency and validity, properly developed scoring procedures should be used. Different assessment methods require different forms of scoring. Scoring selection items (true or false, multiplechoice, matching) requires the identification of the correct or, in some instances, best answer. Guides for scoring essays might include factors such as the major points to be included in the "best answer" or models or exemplars corresponding to different levels of performance at different age levels and against which comparisons can be made (Committee, 2011). Procedures for judging other performances or products might include specification of the characteristics to be rated in performance terms and, to the extent possible, clear descriptions of the different levels of performance or quality of a product (Hendrickson, 2011). Comments formed as part of scoring should be based on the responses made by the students and presented in a way that students can understand and use them (Johnson, 2014). It further illustrates that, comments, in oral and written form, are provided to encourage learning and to point out correctable errors or inconsistencies in performance. In addition, comments can be used to clarify a result. Such feedback should be based on evidence pertinent to the learning outcomes being assessed. Procedures for summarizing and interpreting results for a reporting period should be guided by a written policy (Koloi-keaikitse, 2017). 
This means that summary comments and grades, when interpreted, serve a variety of functions. They inform students of their progress. Parents, teachers, counselors, and administrators use them to guide learning, determine promotion, and identify students for special attention and to help students develop future plans. Comments and grades also provide a basis for reporting to other schools in the case of school transfer and, in the case of senior high school students, post-secondary institutions and prospective employers. They are more likely to serve their many functions and those functions are less likely to be confused if they are guided by a written rationale or policy sensitive to these different needs. This policy should be developed by teachers, school administrators, and other jurisdictional personnel in consultation with representatives of the audiences entitled to receive a report of summary comments and grades. The finding of the present study raises the issue of formative feedback by closely examining teachers' responses to student's work. For example, if the teacher asks students to provide more details about a written work, the practice is characterized as formative; however, a concern arises as to whether the student know what the instructor meant when he or she asks for elaboration and more details (Wiliam \& Thompson, 2008). Formative feedback contradicts the traditional evaluative comments teachers frequently use, such as well done, good, or great work and more. Chappuis and Stiggins (2013) argue that judgmental feedback not only holds less for value for improvement and student learning, but it also discourages students from learning. Black and Wiliam (2013) assert that formative feedback illuminates students' strengths and weaknesses, provides some suggestion for improvement, and avoids comparing one student with his or her peers. In addition, Black and Wiliam (2013) point out the importance of oral feedback provided by the teacher, enabling students to reflect on their learning. They write, "the dialogue between pupils and a teacher should be thoughtful reflective, focused to evoke and explore understanding... so that all pupils have an opportunity to think and to express their ideas". Given the definitions and characteristics of formative feedback, it is an important component of instruction that occurs while the instruction occurs and enables the instructor to adjust instruction based on students' suppositions respectively.

Thus, reporting of students' progress takes the form of written reports and conferences (Roemer, 1999). Conferences are face-to-face events involving teacher, student and parents in various combinations for different purposes (students taking the lead in sharing their learning with their parents serves the purpose of encouraging them to take responsibility for their learning (Johnson, 2014). Lastly, those who argue for using traditional assessments argue that just like other forms of assessments, traditional tests are also focused on improving the cognitive side of instruction, i.e. the skills and knowledge that students are expected to develop within a short period of time (Segers \& Dochy, 2001). A study conducted by Kleinert, Kennedy, and Kearns (1999) revealed that teachers expressed levels of frustration in the use of alternative assessments such as portfolio assessment. Some major issues that teachers have against the use of alternative assessments are that they require more time for students to complete, and for teachers to supervise and assess. Thus, the teachers are generally also concerned about competencies they have in reliably grading these forms of assessments and that such assessments are more teacher-based than student-based. The findings also affirmed that evaluation and grading are good performance indicators even in the graduate level, wherein the faculty must be outstanding in elucidating the grading system to students by using outcomes and other requirements as pointers of the scholarly level of student performance in every subject (Bueno, 2017).

\section{Relationship between Assessment Skills and Practices}

Among EST, the value of R is 0.713 and the coefficient of determination is 0.508 . Thus, there is a moderate positive correlation between assessment skills and practices of elementary school teachers, which means there is a tendency for a skilled teacher in the preparation of the assessment tool to frequently use the same tool in the classroom (and vice versa). Among JHST, the value of R is 0.634 and the coefficient of determination is 0.402 . Thus, there is a moderate positive correlation between assessment skills and practices of junior high school teachers, which means by normal standards, the association between the skills and the practices of teachers would be considered statistically significant. Moreover, similar result of moderate positive correlation is obtained among SHST, because the value of $\mathrm{R}$ is 0.655 and the coefficient of determination is 0.429 . Therefore, teachers adopt a variety of classroom assessment practices to evaluate student learning outcomes, and spend much classroom time engaged in assessment-related activities. Teachers typically control classroom assessment environments by choosing how they assess their students, the frequency of these assessments, and how they provide assessment feedback. For these reasons, it is imperative for them to be competent in the various classroom assessment tools (Koloi-keaikitse, 2017). The findings of the study affirm that primarily the current practices of assessment were focused on exams, classroom discussions, classroom assignment, projects, and seminars. In addition, the study found out that an informal exposure to formative assessment (alternative approach) existed among the faculty members and based on students' responses, overall, as a formal approach, alternative assessment was considered as a new paradigm (Ahmad \& 
Mussawy, 2009). Teachers depend on the classroom assessment information to improve their instructional methods, and as such, that information plays an important role in student learning. It is apparent that teachers should be made competent in the collection, analysis and use of assessment information. Zhang and Burry-Stock (2003) argued that to be able to communicate assessment results more effectively, teachers must possess a clear understanding about the limitations and strengths of various assessment methods. Teachers must also use proper terminology as they use assessment results to inform other people about the decisions about student learning. For this reason, teacher educators must find ways in which they can improve their assessment training methods that can equip teachers with needed skills for using and communicating assessment results. This finding equally brings major challenges to school administrators who rely on teachers to provide them with information about student learning that they collect from assessment results. It is clear that items that assessed teachers' perceived skills about test construction are helpful in providing essential information about teachers' perceived skills in classroom assessment practices. This finding is important because it shows that if school managers want to know assessment areas that teachers may need to be trained on, they may not ask them about their perceived skills in test construction, but rather they may want to establish if teachers are more confident in using assessment information for improving their instructional methods, or whether they are in a position to communicate assessment results for better decision-making about student learning. These results generally imply the need for teachers or assessment professional development specialists to focus their attention on assessment training on skills teachers need most and those they have less perceived skills on. Teachers are one of the key elements in any school and effective teaching is one of the key propellers for school improvement. This study is concerned with how to define a teacher's effectiveness and what makes an effective teacher in relation to their skills and actual practices in assessing students' learning. It draws out implications for policymakers in education and for improving classroom practice. Thus, the results of this study suggest that, although most teachers claimed that their training did have a certain impact on their assessment practices, the changes occurred mostly while the teachers were novice teachers. This finding also indicates that teachers are required to attend workshops or courses to acquire updated assessment knowledge from time to time. Teacher training programs can equip teachers with assessment knowledge by offering assessment courses to pre-service teachers and assessment workshops to inservice teachers.

\section{CONCLUSIONS AND RECOMMENDATIONS}

The teachers across levels from elementary to senior high school are very skilled calculating central tendency of teacher-made tests, assessing students' class participation, calculation of grades, using assessment results in planning, decision-making, communicating and providing feedback, problem solving, evaluating class improvement, and writing true or false tests. Moreover, they are skilled in writing multiple-choice tests measuring higher order thinking skills (HOTS). However, they are moderately skilled in developing rubrics, and calculating variability for teacher-made tests. All the teachers across levels are always preparing and employing multiple-choice question, true or false and essay questions, HOTS, problem solving, assessment results for decision-making and written feedback along with student's grades. Moreover, they oftentimes employ assessment of individual student's class participation, results in lesson planning, and evaluating class and student's improvement, communicate assessment result, and table of specifications. However, they sometimes use item analysis, revise test items, peer assessment, and rubrics in classroom assessment, and they seldom use the results of standard deviation for teachermade tests. There is a moderate positive correlation between the assessment skills and the assessment practices of elementary, junior, and senior high school teachers. Additionally, the results showed that items asking teachers about their perceived skills in test construction and calculation of statistical techniques such as measures of central tendency were the least useful in understanding overall perceptions about assessment skills. Further examination of the results showed that an item that asked teachers about their perceived skill in portfolio assessment proved to be the most difficult for teachers to use, an indication that most of the teachers were less skilled in portfolio assessment. This means using traditional forms of assessment such as true or false, multiple choice items and essay questions are more preferred by the teachers compared to the alternative assessments such as portfolio assessments. Thus, the findings of the study revealed the perceived strengths and weaknesses of teachers relative to their classroom assessment skills and practices. These findings have major implications for teacher educators and school managers. For teacher educators these results highlight classroom assessment areas that they may need to focus on as they teach assessment courses. Assessment entails a broad spectrum of activities that includes collection of information for decision-making. The responsibility of teachers is to collect information through various assessment methods that can be used to make informed decisions about students' learning progress. The question is: are teachers competent enough to use or apply 
assessment information for making students' learning decisions? From these results it was very clear that teachers are less confident in using assessment information to make informed instructional and learning decisions. The teachers should continue bringing change and preparing students for future endeavors though authentic assessment. It is therefore imperative to understand their teaching practices particularly how they assess and evaluate student learning outcomes. The gathered information should be used to highlight the level of teachers' competences in conducting classroom assessments towards planning and conducting teachers' education and professional development. It is now essential for researchers, educators, and policy-makers in the Philippine context to have a clear understanding of the perceived skills teachers hold about certain classroom assessment practices as it can open avenues informing policy and practice for addressing the needs that teachers have as they wrestle with their day-to-day classroom assessment practices. Furthermore, research to establish why teachers felt least competent and in the use of portfolio assessment is highly recommended.

\section{ACKNOWLEDGMENT}

The authors acknowledge the assistance of the research coordinators, faculty from the basic education and college, non-teaching staff, for the distribution and retrieval of the survey form and the Research and Publications Office of the Columban College, Inc. for funding the study.

\section{REFERENCES}

[1] Airasian, P. W. (2011). Classroom assessment: Concepts and applications. New York: McGraw-Hill.

[2] Ahmad, S., \& Mussawy, J. (2009). Assessment Practices: Student's and Teachers' Perceptions of Classroom Assessment. Master's Capstone Projects. 9. http://scholarworks.umass.edu/cie_capstones/9

[3] Arter, J. A. \& Spandel, V. (2012). Using Portfolios of student work in Instruction and Assessment. Educational Measurement; Issues and Practice, 26 - 44.

[4] Black, P., Harrison, C., Lee, C., Marshall, B., \& Wiliam, D. (2013). Assessment for learning: Putting it into practice. Buckingham, UK: Open University Press.

[5] Bombly, Sarah Mirlenbrink, "Reading Assessment Practices of Elementary General Education Teachers: A Descriptive Study" (2013). Graduate Theses and Dissertations. http://scholarcommons.usf.edu/etd/4866

[6] Brookhart, S. M. (2011). Educational assessment knowledge and skills for teachers. Educational Measurement: Issues and Practice, 30, 3-12. http://dx.doi.org/10.1111/j.1745-3992.2010.00195.x

[7] Bueno, D. (2017). Research Skills of the Professorial Lecturers: Input to Capability Building. JPAIR Institutional Research, 9(9), 117. doi:10.7719/irj.9i9.489

[8] Campbell, C., \& Evans, J. A. (2000). Investigation of preservice teachers' classroom assessment practices during student teaching. Journal of Educational Research https://doi.org/10.1080/00220670009598729

[9] Cavanagh, R.F., Waldrip, B.G., Romanoski, J.T., Fisher, D.L., and Dorman, J.P. (2005). Measuring student perceptions of classroom assessment. Paper presented at the 2005 Annual Meeting of the
Australian Association for Research in Education: Parramatta. $\begin{array}{llll}\text { Retrieved September } & 5, & 2009 & \text { at }\end{array}$ http://docs.google.com/gview?a=v\&q=cache:jokRTIUCmK4J:https:/ /www.aare.edu.au/05pap/cav05748.pdf+Measuring+student+percept ions+of+classroom+assessment\&hl=en\&gl=us

[10] Chappuis, S., \& Stiggins, R. J. (2013). Classroom assessment for learning. Educational Leadership, 60, 40-43.

[11] Chih-Min, S. \& Li-Yi, W. (2016). Factors Affecting English Language Teachers' Classroom Assessment Practices A case study at Singapore secondary schools. NIENTU Singapore Research Brief, 13, 10. www.nie.edu.sg

[12] Cizek, G. J., Germuth, A. A., \& Schmid, L. A. (2013). A checklist for evaluating K-12 assessment programs. Kalamazoo: The Evaluation Center, Western Michigan University. Available from http://www.wmich.edu/evalctr/checklists/

[13] Damian, V. B. (2014). Portfolio assessment in the classroom. Helping children at home and school II: Handout for families and educators, S3 - 129 - S3 - 131.

[14] DeLuca, C., \& Klinger, D. A. (2010). Assessment literacy development: Identifying gaps in teacher candidates' learning. Assessment in Education: Principles, Policy \& Practice, 17, 419438. doi:10. 1080/0969594X.2010.516643 https://doi.org/10.1080/0969594X.2010.516643

[15] Dillman, D. A., Smyth, J.D., \& Christian, L. M. (2009). Internet, mail, and mixed-mode surveys: The tailored design method (3rd ed.). Hoboken, New Jersey: John Wiley \& Sons.

[16] Flórez, M.T. \& Sammons, P. (2013). Assessment for learning: effects and impact. Oxford University Department of Education. Copyright CfBT Education Trust 2013.

[17] Gay, L. R., Mills, G. E., \& Airasian, P. (2009). Educational research competencies for analysis and applications. Columbus, GA: Pearson Merrill Prentice Hall. https://doi.org/10.1016/j.jmaa.2008.10.022

[18] Gonzales, R. \& Fuggan, F. G. (2012). Exploring the conceptual and psychometric properties of classroom assessment. The International Journal of Educational and Psychological Assessment, 9(2), 45-60.

[19] Hambleton, R. K., Swaminathan, H., \& Rogers, H. J. (1991). Fundamentals of item response theory: Measurement methods for the social sciences series (Vol. 2). New York, NY: Sage

[20] Hays, R. D., Morales, L. S., \& Reise, S. P. (2000). Item response theory and health outcomes measurement in the 21 st century. Medical Care, 38, II28-II42. https://doi.org/10.1097/00005650-200009002-00007

[21] Hendrickson, K. A. (2011). Assessment in Finland: A Scholarly Reflection on One Country's Use of Formative, Summative, and Evaluative Practices. Mid-Western Educational Researcher, 25 (25), 33-43.

[22] Johnson, S. (2012) Assessing Learning in the Primary Classroom. London: Routledge.

[23] Johnson, S. (2014) On the reliability of high-stakes teacher assessment, Research Papers in Education, 18(1), 91-105.

[24] Koh, K. H. (2011). Improving teachers' assessment literacy through professional development. Teaching Education, 22, 255-276. http://dx.doi.org/10.1080/10476210.2011.593164

[25] Koloi-Keaikitse, S. (2012). Classroom Assessment Practices: a Survey of Botswana Primary and Secondary School Teachers. Cogent Education, 38(1), 1-14. https://doi.org/10.1080/2331186X.2017.1281203

[26] Koloi-keaikitse, S. (2017). Assessment of teacher perceived skill in classroom assessment practices using IRT Models. Cogent Education, 38(1), 1-14. https://doi.org/10.1080/2331186X.2017.1281202

[27] Looney, A. (2014). Assessment and the reform of education systems. In C. Wyatt-Smith, V. Klenowski, \& P. Colbert (Eds.), Designing assessment for quality learning. Heidelberg: Springer https://doi.org/10.1007/978-94-007-5902-2_15.

[28] Looney, A., Cumming, J., Kleij, F. Van Der, \& Harris, K. (2017). Reconceptualising the role of teachers as assessors: teacher assessment identity. Assessment in Education: Principles, Policy \& 
Practice,

(January),

https://doi.org/10.1080/0969594X.2016.1268090

[29] Lyon, E. G. (2011). Beliefs, practices and reflection: Exploring a science teacher's classroom assessment through the assessment triangle model. Journal of Science Teacher Education, 22, 417-435. http://dx.doi.org/10.1007/s10972-011-9241-4

[30] Lysaght, Z., \& O'Leary, M. (2013). An instrument to audit teachers' use of assessment for learning. Irish Educational Studies, 32, 217 232. doi:10.1080/03323315.2013.784636 https://doi.org/10.1080/03323315.2013.784636

[31] McMillan, J. M. (2008). Assessment essentials for student-based education (2nd ed.). Thousand Oaks: Crown Press.

[32] Mellenbergh, G. J. (1994). Generalized linear item response theory. Psychological Bulletin, 115, 300-307. doi:10.1037/00332909.115.2.300 https://doi.org/10.1037/0033-2909.115.2.300

[33] Mertens, D. M. (2014). Research and evaluation in education and psychology. Integrating diversity with quantitative and qualitative and mixed methods (3rd ed.). California: Sage Publications, Inc.

[34] Mullis, I. V. S., \& Martin, M. O. (2015). Assessment Frameworks. TIMMS and Pirls International Study Center, Boston College.

[35] Ndalichako, J. L. (2014). Towards an understanding of assessment practices of primary school teachers in Tanzania. Zimbabwe Journal of Education Research, 16(3), 168-177. Available on http://dx.doi.org/10.4314/zjer.v16i3.26046.

[36] Ndalichako, J.L. (2017). Examining Classroom Assessment Practices of Secondary School Teachers in Tanzania. National Examinations Council of Tanzania

[37] Nenty, H. J., Adedoyin, O. O., Odili, J. N., \& Major, T. E. (2007). Primary teachers' perceptions of classroom assessment practices as means of providing quality primary and basic education by Botswana and Nigeria. Educational Research and Review

[38] Panadero, E., Brown, G., \& Courtney, M. (2014). Teachers' reasons for using self-assessment: A survey self-report of Spanish teachers. Assessment in Education: Principles, Policy \& Practice, 21, 365383. doi:10.1080/0969594X.2014.919247 https://doi.org/10.1080/0969594X.2014.919247

[39] Panadero, E., Brown, G., \& Courtney, M. (2014). Teachers' reasons for using self-assessment: A survey self-report of Spanish teachers. Assessment in Education: Principles, Policy \& Practice, 21, 365383. doi:10.1080/0969594X.2014.919247 https://doi.org/10.1080/0969594X.2014.919247

[40] Popham, W.J. (2008). Classroom assessment: What teachers need to know? 5th Ed. Boston: Ally and Bacon.

[41] Price, J. K, Pierson, E. \& Light D. (2011). Using Classroom Assessment to Promote 21st Century Learning in Emerging Market Countries. Paper presented at Global Learn Asia Pacific 2011, Melbourne Australia

[42] Pryor, J., \& Crossouard, B. (2010). Challenging formative assessment: Disciplinary spaces and identities. Assessment \& Evaluation in Higher Education, 35, 37-41. doi:10.1080/02602930903512891 https://doi.org/10.1080/02602930903512891

[43] Roemer, K. L. (1999). Student evaluation practices used by Montessori elementary teachers. The University of Memphis Review, 22(19), 23-25

[44] Stiggins, R. J., \& Bridgeford, N. J. (2014). The ecology of classroom assessment. Journal of Educational Measurement, 22(4), 271-286 https://doi.org/10.1111/j.1745-3984.1985.tb01064.x

[45] Sweet, D. (2013). Student Portfolios: Classroom Uses. Education Consumer Guide No. 8. Retrieved from http://www2.ed.gov/pubs/OR/ConsumerGuides/classesuse.html.

[46] Warsen, G. D. (2013). Making Grades Matter: Connections Between Teacher Grading Practices and Attention to State $\begin{array}{llll}\text { Assessment. Dissertations. } & \text { Paper } & 156 .\end{array}$ http://scholarworks.wmich.edu/dissertations Part

[47] Wiliam, D., \& Thompson, M. (2008). Integrating assessment with learning: What will it take to make it work? In C. A. Dwyer (Ed.).
The future of assessment: Shaping teaching and learning.. New York: Lawrence Erlbaum Associates.

[48] Wolf, P. (2011). Academic improvement through regular assessment. Peabody Journal of Education, 82(4), 690-702. https://doi.org/10.1080/01619560701603114

[49] Wiggins, G. P. (2008). Educative assessment: Designing assessments to inform and improve student performance. San Francisco: Jossey-Bass Publishers.

[50] Wyatt-Smith, C. M., \& Looney, A. (2016). Professional standards and the assessment work of teachers. In D. Wyse, L. Hayward, \& J. Pandaya (Eds.), The Sage handbook of curriculum, pedagogy and assessment (pp. 805-820). London: Sage https://doi.org/10.4135/9781473921405.n50

[51] Wyatt-Smith, C., \& Klenowski, V. (2013). Explicit, latent and metacriteria: Types of criteria at play in professional judgement practice. Assessment in Education: Principles, Policy \& Practice, 20, 35-52. doi:10.1080/0969594X.2012.725030 https://doi.org/10.1080/0969594X.2012.725030

[52] Xu, Y., \& Brown, G. (2016). Teacher assessment literacy in practice: A reconceptualization. Teaching and Teacher Education, 58, 149-162. doi:10.1016/j.tate.2016.05.010 https://doi.org/10.1016/j.tate.2016.05.010

[53] Young, J. E. J., \& Jackman, M. G. (2014). Formative assessment in the Grenadian lower secondary school: Teachers' perceptions, attitudes and practices. Assessment in Education: Principles, Policy \& Practice, 21, 398-411. doi:10.1080/0969594X.2014.919248 https://doi.org/10.1080/0969594X.2014.919248

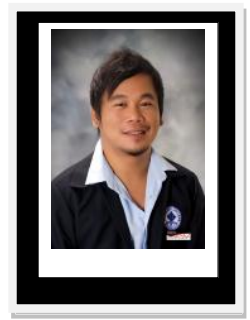

Prof. David Cababaro Bueno is a holder of Doctor of Education, Master of Arts in Science Education, Master in Public Management, Master in Business Administration, and Bachelor of Arts degrees. $\mathrm{He}$ is a candidate for graduation leading to the degree of Doctor in Business Administration and currently taking Doctor in Public Management. He authored and co-authored books in Research Writing, Statistics, Biological, Physical and Environmental Sciences, Human Resource Management, Organization and Management, and Curriculum Development. He is currently the Dean of the Graduate School and concurrent Director of Research and Publications at Columban College, Inc. Dr. Bueno is an active member of various national and international professional organizations, research technical committee and reviewer of various international conferences, seminar-workshop speaker and multi-awarded research presenter in the ASEAN community.

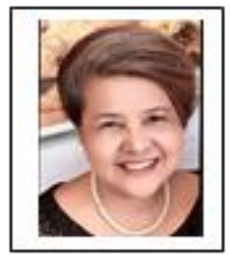

Dr. N. Figuerres is Dean of Magsaysay Memorial College in Zambales, and a Graduate School Professor at CCI. She is President of the Philippine Association for Teachers and Education-Region III Chapter, and well-rounded academician.

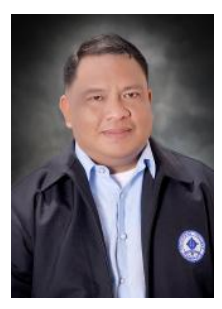

Dr. Redondo is Principal of the Basic Education Department and concurrent Director of Research and Publications Office of Columban College, Inc.Olongapo City. 